\title{
Controlled Study of Atenolol in Treatment of Hypertension
}

\author{
L. HANSSON, H. ÅBERG, B. E. KARLBERG, A. WESTERLUND
}

British Medical fournal, 1975, 2, 367-370

\section{Summary}

The antihypertensive effect of atenolol, a new $\beta-1$ receptor blocking agent, was studied in a double-blind trial in which 45 patients with essential hypertension were randomly assigned to placebo or atenolol treatment. Atenolol caused a statistically significant and clinically relevant reduction of blood pressure. The optimum daily dose for moderately severe hypertension was considered to be $200 \mathrm{mg}$. Several irrelevant side effects were collected by the use of a check list, but there was no difference in the number of complaints during placebo and active treatment. Atenolol has a useful antihypertensive effect and, at least theoretically, has advantages over other $\beta$-adrenergic blocking agents.

\section{Introduction}

$\beta$-Adrenergic blocking agents, mainly propranolol, have been used to treat hypertension for a decade..$^{1-4}$ The increasing use of these agents in hypertension is due partly to their effectiveness in reducing raised arterial pressure-propranolol has been claimed to be as effective as guanethidine ${ }^{2}$-and partly to their relative lack of unwanted effects, such as postural hypotension or hypotension during physical exercise. ${ }^{2} 3$

We have used propranolol as the drug of first choice in the treatment of hypertension for four years and have been generally satisfied with its antihypertensive effect and lack of side effects. Nevertheless, there is always room for improvement in the quality of medical care-for example, by the introduction of improved drugs.

Atenolol (4-(2-hydroxy-3-isopropylaminopropoxy) phenylacetamide) is a new $\beta$-adrenergic blocking compound (see fig.). Animal studies have shown that it is a specific inhibitor of $\beta$-1-receptors (cardioselective), possesses no intrinsic sympathomimetic effects, has no membrane-stabilizing effect (quinidinelike or myocardial depressant action), ${ }^{5}$ and does not cross the blood-brain barrier in autoradiography studies in mice. Its plasma half life in man is five to six hours-longer than that of propranolol. So far no metabolites with $\beta$-blocking properties have been identified, and atenolol is largely excreted in unaltered form.

Theoretically atenolol seems to offer certain advantages in the treatment of hypertension: its lack of sympathomimetic effect might be a positive factor in reducing blood pressure whereas the lack of a $\beta$-2-receptor blocking effect and its inability to cross the blood-brain barrier might reduce or abolish side

Department of Internal Medicine 1, Sahlgren's Hospital (University of Gothenburg), Gothenburg, Sweden

L. HANSSON, M.D., Associate Professor

A. WESTERLUND, M.D., Senior Staff Physician

Department of Internal Medicine, Academic Hospital, Uppsala, Sweden

H. ÅBERG, M.D., Associate Professor

Department of Internal Medicine, University Hospital, Linköping,

B. E. KARLBERG, M.D., Associate Professor

effects such as bronchial obstruction and complaints related to the central nervous system (C.N.S.) that are seen with other $\beta$-blockers. Our first clinical observations in 20 hypertensive inpatients were quite promising, ${ }^{6}$ and since then we have treated a larger group of hypertensive outpatients. ${ }^{7}$ We have treated more than 100 patients with atenolol for up to two years.

Our purpose in this study was to determine the antihypertensive effect of atenolol in a controlled study and try to determine its optimum dosage in mild to moderately severe essential hypertension.

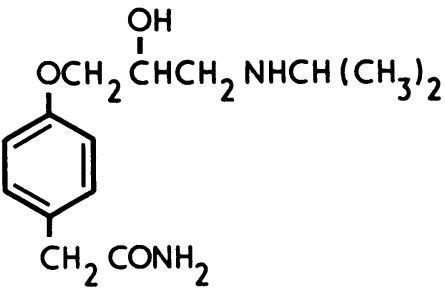

Structural formula of atenolol.

\section{Patients and Methods}

Forty-five patients, 26 men and 19 women, with an average age of 43 years (range 16-70) were recruited to a multicentre trial (table I). All but 11 had received no treatment. As the study was double blind without crossover the patients were randomly referred to 16 weeks' treatment with placebo (group 1) or atenolol (group 2). Because of this design we recruited only patients with relatively mild hypertension; patients with recumbent diastolic blood pressures higher than $115 \mathrm{~mm}$ $\mathrm{Hg}$ were excluded. Even in group 2 only placebo was given during the first four weeks; patients then received atenolol (Tenormin) $50 \mathrm{mg}$ twice a day for the second four weeks, $100 \mathrm{mg}$ twice a day for the next four weeks, and $200 \mathrm{mg}$ twice a day for the last four weeks. During all periods the patients received two tablets a day. No other drugs were given during the trial.

Blood pressure and heart rate were recorded in a standardized fashion using mercury sphygomanometers with $13-\mathrm{cm}$ cuffs at the beginning of the study and then every four weeks. Recumbent blood pressure and heart rate were determined after five minutes of supine rest. Standing blood pressure was measured after two minutes' standing. Diastolic blood pressure was taken at the disappearance of the Korotkoff sounds (phase V). Data on heart rate were withheld from the doctors during the study. At the end of each four-week period the patients were questioned for side effects with the aid of a specially designed check list. At the beginning and end of the trial the following laboratory values were determined: haemoglobin, packed cell volume, white blood count, differential white cell count, serum aspartate aminotransferase, serum alanine aminotransferase, bilirubin, alkaline phosphatase, serum urate and creatinine, and urinary glucose and protein.

Comparisons of blood pressure and heart rate between groups 1 and 2 were made by Student's $t$ test. Comparisons of blood pressure within group 2 at the different dosages of atenolol were made by the $t$ test for paired observations. $P$ values less than 0.05 were considered significant.

\section{Results}

There were no significant differences in blood pressure or heart rate between groups 1 and 2 either at admission to the study or after four weeks of placebo treatment in both groups. After the second, third, and fourth four-week periods, when group 2 received atenolol, there were highly significant differences between the two groups in both blood pressure and heart rate (tables II and III). 
TABLE I-Details of Patients on Placebo (Group 1) and Atenolol (Group 2)

\begin{tabular}{|c|c|c|c|c|c|c|c|c|c|}
\hline & \multirow{2}{*}{$\begin{array}{c}\text { No. of } \\
\text { Patients }\end{array}$} & \multicolumn{2}{|c|}{ Sex } & \multirow{2}{*}{$\begin{array}{c}\text { Mean Age } \\
\text { (Years) }\end{array}$} & \multirow{2}{*}{$\begin{array}{c}\text { Mean } \\
\text { Duration } \\
\text { of } \\
\text { Hypertension } \\
\text { (Years) }\end{array}$} & \multicolumn{3}{|c|}{$\begin{array}{l}\text { Eyeground Data* } \\
\text { (No. of Patients) }\end{array}$} & \multirow{2}{*}{$\begin{array}{l}\text { No. with } \\
\text { Ventricular } \\
\text { Hypertrophy } \\
\text { on E.C.G. } \\
\text { or Chest } \\
x \text {-Ray Film }\end{array}$} \\
\hline & & M. & F. & & & K.W.W. & K.W.B. & K.W.B. & \\
\hline $\begin{array}{l}\text { Group } 1 \\
\text { Group } 2\end{array}$ & $\begin{array}{l}23 \\
21\end{array}$ & $\begin{array}{l}13 \\
13\end{array}$ & $\begin{array}{r}10 \\
8\end{array}$ & $\begin{array}{l}45 \\
42\end{array}$ & $\begin{array}{l}2 \cdot 3 \\
2 \cdot 3\end{array}$ & $\begin{array}{l}9 \\
6\end{array}$ & $\begin{array}{r}8 \\
13\end{array}$ & $\begin{array}{l}6 \\
2\end{array}$ & $\begin{array}{l}3 \\
2\end{array}$ \\
\hline
\end{tabular}

${ }^{*}$ K.W.B. = Keith-Wagener-Barker classification.

TABLE II-Effects of Treatment with Placebo and Atenolol on Recumbent Blood Pressure and Heart Rate. Values are Means \pm S.E. of Mean

\begin{tabular}{|c|c|c|c|c|c|c|c|}
\hline & \multicolumn{3}{|c|}{ Group 1} & \multicolumn{4}{|c|}{ Group 2} \\
\hline & \multicolumn{2}{|c|}{ Blood Pressure } & \multirow{2}{*}{ Heart Rate } & \multirow{2}{*}{$\begin{array}{c}\text { Dose of Atenolol } \\
\text { (mg/b.i.d.) }\end{array}$} & \multicolumn{2}{|c|}{ Blood Pressure } & \multirow{2}{*}{ Heart Rate } \\
\hline & Systolic & Diastolic & & & Systolic & Diastolic & \\
\hline $\begin{array}{l}\text { At admission } \\
\text { At } 4 \text { weeks } \\
\text { At } 8 \text { weeks } \\
\text { At } 12 \text { weeks } \\
\text { At } 16 \text { weeks }\end{array}$ & $\begin{array}{l}169 \cdot 0 \pm 4 \cdot 1 \\
164.8 \pm 4.4 \\
160 \cdot 3 \pm 4.4 \\
163.0 \pm 4.5 \\
165.9 \pm 4.8\end{array}$ & $\begin{array}{r}107 \cdot 4 \pm 1 \cdot 9 \\
102.9 \pm 2.7 \\
100 \cdot 3 \pm 2 \cdot 2 \\
99 \cdot 0 \pm 2.4 \\
101.9 \pm 2.8\end{array}$ & $\begin{array}{l}80 \cdot 1 \pm 1 \cdot 8 \\
80 \cdot 4 \pm 2 \cdot 3 \\
76 \cdot 9 \pm 2 \cdot 4 \\
78 \cdot 5 \pm 2 \cdot 2 \\
80 \cdot 3 \pm 2 \cdot 7\end{array}$ & $\begin{array}{r}50 \\
100 \\
200\end{array}$ & $\begin{array}{l}168.6 \pm 3 \cdot 6 \\
161.1 \pm 3 \cdot 8 \\
142.5 \pm 4 \cdot 1^{*} \\
142.4 \pm 4 \cdot 0^{*} \\
137.9 \pm 3 \cdot 4^{*}\end{array}$ & $\begin{array}{c}105 \cdot 2 \pm 1 \cdot 9 \\
103 \cdot 0 \pm 2 \cdot 1 \\
89 \cdot 0 \pm 2 \cdot 1^{*} \\
84 \cdot 1 \pm 1 \cdot 8^{*} \\
84 \cdot 1 \pm 2 \cdot 0^{*}\end{array}$ & $\begin{array}{l}81 \cdot 8 \pm 2 \cdot 6 \\
77 \cdot 8 \pm 1 \cdot 9 \\
61 \cdot 2 \pm 2 \cdot 3 * \\
58 \cdot 7 \pm 2 \cdot 1^{*} \\
54 \cdot 5 \pm 1 \cdot 5 *\end{array}$ \\
\hline
\end{tabular}

*Significantly different from corresponding measurement in group 1, at $\mathrm{P}<0.005$ (Student's $t$ test).

TABLE III-Effects of Treatment with Placebo and Atenolol on Standing Blood Pressure. Values are Means \pm S.E. of Mean

\begin{tabular}{|c|c|c|c|c|c|}
\hline & \multicolumn{2}{|c|}{ Group 1} & \multicolumn{3}{|c|}{ Group 2} \\
\hline & \multicolumn{2}{|c|}{ Blood Pressure } & \multirow{2}{*}{$\begin{array}{l}\text { Dose of Atenolol } \\
\text { (mg/b.i.d.) }\end{array}$} & \multicolumn{2}{|c|}{ Blood Pressure } \\
\hline & Systolic & Diastolic & & Systolic & Diastolic \\
\hline $\begin{array}{l}\text { At admission } \\
\text { At } 4 \text { weeks } \\
\text { At } 8 \text { weeks } \\
\text { At } 12 \text { weeks } \\
\text { At } 16 \text { weeks }\end{array}$ & $\begin{array}{l}166.2 \pm 4.5 \\
163.9 \pm 4.8 \\
163.5 \pm 4.4 \\
164.4 \pm 4.5 \\
163.8 \pm 4.4\end{array}$ & $\begin{array}{l}114.9 \pm 2.1 \\
111.7 \pm 2.6 \\
109.8 \pm 2.3 \\
108.7 \pm 2.2 \\
110.7 \pm 2.9\end{array}$ & $\begin{array}{r}50 \\
100 \\
200\end{array}$ & $\begin{array}{l}169 \cdot 2 \pm 4 \cdot 3 \\
161 \cdot 3 \pm 4 \cdot 2 \\
142 \cdot 5 \pm 4 \cdot 2 * \\
140 \cdot 6 \pm 4 \cdot 6^{*} \\
138 \cdot 9 \pm 4 \cdot 0^{*}\end{array}$ & $\begin{array}{r}110.3 \pm 1.9 \\
110.5 \pm 2 \cdot 2 \\
98.3 \pm 2 \cdot 2^{*} \\
91.8 \pm 1.6^{*} \\
92.1 \pm 1.8^{*}\end{array}$ \\
\hline
\end{tabular}

*Significantly different from corresponding measurement in group 1, at $\mathrm{P}<0.005$ (Student's $t$ test).

TABLE IV-Number of Side Effects Complained of in Each Group and on Each Dose of Atenolol

\begin{tabular}{|c|c|c|c|c|c|}
\hline & \multirow{2}{*}{$\begin{array}{l}\text { Group } 1 \\
\text { Placebo }\end{array}$} & \multicolumn{4}{|c|}{ Group 2} \\
\hline & & Placebo & $\begin{array}{c}\text { Atenolol } \\
\text { (50 mg/b.i.d.) }\end{array}$ & $\begin{array}{c}\text { Atenolol } \\
\text { (100 mg/b.i.d.) }\end{array}$ & $\begin{array}{c}\text { Atenolol } \\
\text { (200 mg/b.i.d.) }\end{array}$ \\
\hline \multirow{9}{*}{$\begin{array}{l}\text { Cardiac awareness } \\
\text { Respiratory symptoms } \\
\text { Muscle symptoms } \\
\text { Headaches } \\
\text { Nasal congestion } \\
\text { Drowsiness } \\
\text { Insomnia } \\
\text { Vertigo } \\
\text { Nausea } \\
\text { Heartburn } \\
\text { Flatulence } \\
\text { Obstipation } \\
\text { Loose stools } \\
\text { Cold limbs } \\
\text { Miscellaneous }\end{array}$} & \multirow{9}{*}{$\begin{array}{l}2 \\
3 \\
2 \\
5 \\
3 \\
6 \\
6 \\
5 \\
2 \\
3 \\
3 \\
1 \\
3\end{array}$} & \multirow{4}{*}{$\begin{array}{l}2 \\
3 \\
1 \\
2\end{array}$} & \multirow{3}{*}{$\begin{array}{l}1 \\
2 \\
3\end{array}$} & \multirow{3}{*}{$\begin{array}{l}1 \\
1 \\
3 \\
1\end{array}$} & \multirow{4}{*}{$\begin{array}{l}1 \\
2 \\
2 \\
2 \\
3\end{array}$} \\
\hline & & & & & \\
\hline & & & & & \\
\hline & & & 2 & 2 & \\
\hline & & 4 & $\begin{array}{l}\mathbf{4} \\
\mathbf{3}\end{array}$ & $\begin{array}{l}3 \\
1\end{array}$ & \multirow{3}{*}{$\begin{array}{l}2 \\
3 \\
2 \\
3\end{array}$} \\
\hline & & 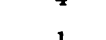 & 1 & 1 & \\
\hline & & 1 & 2 & 1 & \\
\hline & & \multirow[t]{2}{*}{1} & $\begin{array}{l}2 \\
2\end{array}$ & 2 & \multirow{2}{*}{1} \\
\hline & & & $\overline{1}$ & $\overline{1}$ & \\
\hline Total & 45 & 14 & 23 & 17 & 21 \\
\hline
\end{tabular}

Comparisons of recumbent blood pressure within group 2 to evaluate the effect of different doses of atenolol showed that a further and significant reduction of diastolic blood pressure occurred when $200 \mathrm{mg}$ was given instead of $100 \mathrm{mg}$ daily $(\mathrm{P}<0.01)$. A further increase to $400 \mathrm{mg}$ daily did not, however, produce a further significant reduction of either systolic or diastolic blood pressure.

Side Effects.-Many side effects were registered during the study. In the placebo group 15 out of 23 patients admitted to 45 complaints. In the actively treated group 15 out of 21 patients had side effects (table IV). The total number of complaints in this group was 75, but 14 were registered during the initial four-week placebo period. Thus, altogether 59 complaints were registered during placebo treatment and 61 during atenolol treatment. One 24-year-old woman withdrew from the study claiming an array of non-specific symptoms. Her decision was undoubtedly influenced by a series of programmes and articles in the newsmedia on herbaceous treatment. No data from this patient were included in the results. No significant or consistent changes in the laboratory values were observed.

\section{Discussion}

In studies similar to ours double-blind crossover techniques have usually been used, the advantages of a crossover being that each patient serves as his own control and the number of patients may be restricted. But drugs with long-lasting effects may exert these effects also during the supposedly drug-free period. This is a problem with many antihypertensive drugs, especially $\beta$-adrenergic blocking agents. ${ }^{8} \mathrm{We}$ have found with both propranolol and atenolol that blood pressure may take several weeks or even months to reach initial levels after treatment has stopped. So unless periods of treatment are very long a double-blind study without crossover is preferable. Hence, we preferred to compare two groups of patients randomly assigned to either placebo or atenolol. There were no significant differences between the two groups in blood pressure or heart rate either at admission to the study or after four weeks of placebo treatment. 
Moreover, the two groups were similar in age, sex distribution, and duration of hypertension. We therefore felt justified in comparing the two groups.

Our results show that atenolol significantly reduces raised blood pressure as compared with placebo. The overall reduction of blood pressure was about the same as that reported in open studies $^{7}$ and comparable to that on propranolol. ${ }^{3}$ Clearly, reductions of arterial pressure of about $30 / 15 \mathrm{~mm} \mathrm{Hg}$ are useful in the treatment of hypertensive patients.

Pharmacologically atenolol's lack of a sympathomimetic effect could be expected to be an advantage, as $\beta$-blockers without this effect seem to be better in reducing blood pressure, at least in severe hypertension. ${ }^{1011}$

\section{OPTIMUM DOSAGE}

Finding the optimum dose is always important when evaluating new drugs. For other $\beta$-adrenergic blocking agents, mainly propranolol, it has been claimed that increasing the daily dose to several grams will produce the desired reduction of blood pressure in most patients. ${ }^{2}$ This has been shown with propranolol in a small series of patients in whom the reduction of diastolic blood pressure was linearly related to daily dosage. ${ }^{12}$ Using plasma propranolol determinations, however, we have been unable to show any persistent and clear-cut relation between dose and plasma propranolol concentration or effect on blood pressure. ${ }^{13}$

Obviously, atenolol differs from propranolol in many important respects-for example, with regard to metabolites with $\beta$-adrenergic blocking effects. Therefore it may be possible to establish a significant relation between dose and plasma concentration with atenolol and, more importantly, between dose and clinical effect, and we are investigating these aspects. We found in this study that a dose of $50 \mathrm{mg}$ twice a day produced a highly significant reduction in blood pressure. A withinpatient comparison in the actively treated group also showed a further, statistically significant, reduction of diastolic recumbent blood pressure when the dose was increased to $100 \mathrm{mg}$ twice a day. No further significant reduction of blood pressure occurred, however, when the dose was increased to $200 \mathrm{mg}$ twice a day.

This might indicate that $200 \mathrm{mg}$ of atenolol is the optimum daily dose when treating patients with relatively mild essential hypertension, but the further reduction of blood pressure at the end of the second four-week period of active treatment might have been an effect of the length of treatment unrelated to the increased dose. It has been claimed that the full antihypertensive effect of propranolol may not be seen until six to eight weeks after the start of treatment, ${ }^{2}$ but this rather slow onset of action could equally well be explained by the low starting dose used. When propranolol was introduced at $160 \mathrm{mg}$ daily the effect on blood pressure occurred after two days' treatment. ${ }^{13}$ Our own results from an ongoing long-term study of atenolol do not suggest a further gradual reduction of arterial pressure after the first month of treatment. For these reasons we feel that the further reduction of recumbent diastolic blood pressure during the second four-week period of active treatment was due to the increment of dosage rather than an effect of prolonged exposure to the drug.

\section{SIDE EFFECTS}

Side effects are vastly over-reported when a check list is used, ${ }^{14}$ and irrelevant symptoms are collected, ${ }^{15}$ so, clearly, our use of a check list interferred with the findings. Nevertheless, some conclusions can be drawn from our results. Firstly, almost the same number of complaints occurred during placebo treatment as during active treatment (59 v. 61), which indicates that atenolol is almost as well tolerated as placebo, and secondly, there was no tendency towards an increasing number of side effects as the dose of atenolol increased.
The true side effects of atenolol were muscle fatigue and cold extremities, and these were often volunteered by patients before they were asked about. As expected, there were no complaints suggestive of bronchial obstruction. Drowsiness was no more common during active treatment than during placebo treatment, and insomnia was never reported on atenolol. This lack of C.N.S. side effects may have been due to atenolol's inability to cross the blood-brain barrier. If this lack of C.N.S. side effects can be confirmed in larger series observed for longer it would constitute a clear advantage for atenolol over many other $\beta$-blockers which are known to cause infrequent C.N.S.-related side effects. ${ }^{2} 4$

Like others ${ }^{7}$ we found no consistent changes in blood and urine laboratory values. As with any new compound, however, only long periods of treatment in many patients will make it possible to draw firm conclusions on toxicology.

\section{ADVANTAGES OF ATENOLOL}

Atenolol's lack of a membrane-stabilizing effect is probably without clinical significance in most therapeutic situations. But it could be an advantage in cases of accidental severe overdosage where a membrane-stabilizing effect, as is seen with many other $\beta$-adrenergic blocking agents, might contribute to myocardial depression and heart failure. Needless to say, the negative inotropism caused by $\beta$-blockade is present with this compound as with all $\beta$-blockers.

The antihypertensive mechanism of $\beta$-adrenergic blocking agents has been much debated during the last few years. Suggestions that propranolol reduces blood pressure directly via its plasma renin lowering effect ${ }^{16}$ have not been confirmed. ${ }^{17}$ Many $\beta$-adrenergic blocking agents-for example, pindolol ${ }^{18}$ and bufuralol ${ }^{19}$-lower blood pressure without reducing plasma renin activity, and the same claim has been made for atenolol. 20 Our studies, however, indicate that atenolol does cause a significant reduction of plasma renin activity, ${ }^{21-28}$ but we are not prepared to state that the effect on renin is causally related to the effect on blood pressure.

Most probably the hypotensive effect of atenolol can be explained on analogy with that of propranolol-that is, long-term treatment caused a chronic reduction of cardiac output with a gradual readjustment of total peripheral resistance and thus reduction of arterial pressure. ${ }^{24}{ }_{25}$ The gradual reduction of total peripheral resistance could be due to an altered baroreceptor sensitivity, ${ }^{26} 27$ or propranolol may lower blood pressure via central nervous effects ${ }^{28}$ and central nervous mechanisms may cause the readjustment of total peripheral resistance-for example, via the baroreceptor mechanism. Central nervous effects of atenolol are less likely to occur, however, as atenolol has been shown not to cross the blood-brain barrier in animals.

\section{References}

1 Prichard, B. N. C., and Gillam, P. M. S., British Medical fournal, 1964,

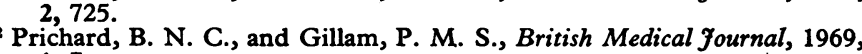
1,7

3 Hansson, L., et al., Klinische Wochenschrift, 1972, 50, 364.

4 Zacharias, F. J., et al., American Heart Yournal, 1972, 83, 755.

5 Barret, A. M. et al., British fournal of Pharmacology, 1973, 48, 340.

- Hansson, L., et al., Acta Medica Scandinavica, 1973, 194, 549 .

${ }^{7}$ Hansson, L., et al., International fournal of Clinical Pharmacology, 1974,

$10,206$.
8 Vedin, J. A., Wilhelmsson, C.-E., and Werkö, L., British Heart fournal, 1973, 35, 1285.

- Frohlich E., D., et al., Circulation, 1968, 37, 417.

10 Kincaid-Smith, P., American fournal of Cardiology, 1973, 32, 575.

11 Berglund, G., and Hansson, L., Acta Medica Scandiravica, 1973, 193, 547.

12 Kincaid-Smith, P., Fang, P, and Laver, M. Clinical Science and Molecular Medicine, 1973, 45, suppi. 1,75 .

${ }^{13}$ Hansson, L., et al., International fournal of Clinical Pharmacology, 1974, 10,79 .

14 Greenblatt, M., Clinical Pharmacology and Therapeutics, 1964, 5, 864.

15 Huskisson, E. C., and Wojtulewski, J. A., British Medical fournal, 1974, 2,698 . 
${ }_{17}$ Buhler, F. R., et al., New England fournal of Medicine, 1972, 287, 1209. 17 Hansson, L., and Zweifler, A. J., Acta Medica Scandinavica, 1974, 195, 397.

18 Stokes, G. S., Weber, M. A., and Thornell, I. R., British Medical fournal, $1974,1,60$

19 George, C. F., Clinical Science and Molecular Medicine, in press.

20 Amery, A., Billiet, L., and Fagard, R., New England fournal of Medicine, $1974,290,284$

${ }^{21}$ Aberg, H., International fournal of Clinical Pharmacology, 1974, 9, 98.
${ }^{22} \mathrm{Karlberg}, \mathrm{B}$. E., in preparation.

${ }^{23}$ Hansson, L., and Aurell, M., in preparation

24 Tarazi, R. C., and Dustan, H. P., American fournal of Cardiology, 1972, $29,633$.

${ }^{25}$ Hansson, L., et al., Acta Medica Scandinavica, 1974, 196, 27.

26 Prichard, B. N. C., and Gillam, P. M. S., American fournal of Cardiology, 1966, 18, 387.

27 Hansson, L., Acta Medica Scandinavica, 1973, Suppl. 550.

28 Dollery, C. T., et al., British fournal of Pharmacology, 1973, 48, 343.

\section{SHORT REPORTS}

\section{Psittacosis and Disseminated Intravascular Coagulation}

Psittacosis most commonly presents as mild pneumonia or pyrexia of undertermined origin. The following patient had severe pneumonia, myocarditis, pericardial effusion, and disseminated intravascular coagulation-a hitherto unreported complication.

\section{Case Report}

A 36-year-old man had felt ill for 10 days, and had dyspnoea, fever, and slight cough with yellow sputum. He was confused, grey, and unwell, being slight cough with yellow sputum. He was confused, grey, and unwell, being
dehydrated with a temperature of $39.7^{\circ} \mathrm{C}$, pulse of $140 /$ minute, and blood dehydrated with a temperature of $39 \cdot 7^{\circ} \mathrm{C}$, pulse of $140 /$ minute, and blood
pressure of $90 / 70 \mathrm{~mm} \mathrm{Hg}$. He was dyspnoeic at rest and had signs of inflampressure of $90 / 70 \mathrm{~mm} \mathrm{Hg}$. He was dyspnoeic at rest and had signs of inflam-
mation in the left lung. A chest $x$-ray film showed extensive opacities in the

During the next 36 hours he deteriorated. An arterial blood sample showed $\mathrm{pH} 7 \cdot 39, \mathrm{Po}_{2} 20 \mathrm{~mm} \mathrm{Hg}$, and $\mathrm{Pco}_{2} 36 \mathrm{~mm} \mathrm{Hg}$. He was intubated and treated with positive pressure ventilation with an oxygen concentration $\left(\mathrm{FIO}_{2}\right)$ of $100 \%$. After one and a half hours of ventilation, his arterial blood gases were $\mathrm{pH} 7 \cdot 30, \mathrm{Po}_{2} 25 \mathrm{~mm} \mathrm{Hg}$, and $\mathrm{Pco}_{2} 33 \mathrm{~mm} \mathrm{Hg}$. He was given intravenous chloramphenicol, fucidin, tetracycline, and intramuscular streptomycin. On the sixth day he developed surgical emphysema on the right side of his neck, though there was no evidence of a pneumothorax. Chest $x$-ray films showed that his heart shadow was becoming larger and more globular in shape, indicative of pericardial effusion. There was never evidence of cardiac failure. Despite a blood transfusion on the fourth day, his ham

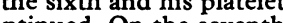
count was $47000 / \mathrm{mm}^{3}$. Chloramphenicol was discontinued. On the seventh day the platelet count was only $40000 / \mathrm{mm}^{3}$. The only clinical evidence of bleeding was skin bruising at the site of venous and arterial punctures. Full coagulation studies were performed (see table), and led to a diagnosis of disseminated intravascular coagulation; heparin (500 units intravenously hourly) was started and continued until the 15 th day. Streptomycin and tetracycline were discontinued and doxycycline begun.

Coagulation Studies

\begin{tabular}{c|c|c|c|c|c}
\hline $\begin{array}{c}\text { Days after } \\
\text { Admission }\end{array}$ & $\begin{array}{c}\text { Platelets } \\
/ \mathrm{mm}^{3}\end{array}$ & $\begin{array}{c}\text { Prothrombin } \\
\text { Time } \\
\text { (Seconds) }\end{array}$ & $\begin{array}{c}\text { Kaolin- } \\
\text { Cephalin } \\
\text { Time } \\
\text { (Seconds) }\end{array}$ & $\begin{array}{c}\text { Fibrinogen } \\
\text { Titre }\end{array}$ & $\begin{array}{c}\text { F.D.P. } \\
\mu \mathrm{g} / \mathrm{ml}\end{array}$ \\
\hline 5 & Reduced & 0 & 0 & 0 & 0 \\
6 & 47000 & 0 & 0 & 0 & 0 \\
7 & 40000 & 3 mins. & 6 mins. & No clot & 320 \\
8 & 79000 & 23 & 45 & $1: 2$ & 320 \\
9 & 47000 & 22 & 37 & $1: 8$ & 320 \\
10 & 43000 & 28 & 59 & $1: 8$ & 320 \\
15 & 140000 & 15 & 36 & $1: 32$ & 40 \\
27 & 172000 & 17 & 48 & 0 & 40 \\
\hline
\end{tabular}

F.D.P. = Fibrinogen degradation products.

By the eighth day his condition and the results of the coagulation studies had improved. On the tenth day he developed multiple ventricular ectopic beats and a short run of ventricular tachycardia. Intravenous lignocaine and oral practolol abolished the ventricular arrhythmias. He then developed difficulty in speaking and was unable to swallow. A tracheostomy was performed and he was ventilated. He maintained his good progress and was disformed and he was ventilated. He maintained his good progress and was discharged 30 days after admission. Antibody titre to psittacosis was $1 / 16$ on the third and seventh day and $1 / 256$ on the thirtieth day. When seen in
follow-up one month later the patient was fit and well, apart from slight follow-up one month later the patient was fit and well, apart from slight
generalized weakness. He mentioned that he kept tropical fish and that his generalized weakness. He mentioned that he kept tropical fish and that his
only contact with birds was in the pet shop from which he bought his fish only con.

\section{Discussion}

Psittacosis usually produces a mild respiratory infection, though occasionally it may cause severe respiratory failure. The mortality is mainly from complications and approaches $5 \% .^{1}$ The considerable hypoxia in this patient necessitated mechanical ventilation. Psittacosis may also involve the cardiovascular system, ${ }^{2}{ }^{3}$ and may damage the liver, producing jaundice. Here it resulted in disseminated intravascular coagulation (D.I.C.), which is characterized by the deficiency of fibrinogen and other clotting factors and thrombocytopenia. Several viruses may cause D.I.C., which may be transient, fatal, or pass unnoticed. The platelet count is almost invariably depressed, but, as here, there is no correlation between the absolute level of circulating platelets and the haemorrhagic tendency.

In treating D.I.C. the first step is to treat its cause-for example, septic shock. ${ }^{4}$ D.I.C. may be reversed with intravenous heparin; in D.I.C. with infectious mononucleosis a suitable dose may be 12000 units over 24 hours. $^{5}$

I should like to thank Lord Waverley and Dr. D. G. Price for their help and for permitting me to report details of a patient under their care, and Drs. J. V. Dadswell, W. A. P. Hamilton, and F. Hampson for reviewing the manuscript.

1 British Medical fournal, 1972, 1, 1.

2 Dymock, I. W., et al., British fournal of Clinical Practice, 1971, 25, 240. 3 Ward, C., and Ward, A. M., Lancet, 1974, 2, 734.

Corrigan, J. J., Jordan, C. M., and Bennet, B. B., American fournal of Diseases of Children, 1973, 126, 629.

5 Dodsworth, H., and Burns, A., British Medical fournal, 1971, 4, 466.

Wexham Park Hospital, Slough, Bucks SL2 4HL

D. V. HAMILTON, M.B., B.CH., House Physician

\section{Severe Peripheral Neuropathy after Mandrax Overdose}

Poisoning with methaqualone and diphenhydramine (which are available in this country as Mandrax tablets containing methaqualone $250 \mathrm{mg}$ and diphenhydramine hydrochloride $25 \mathrm{mg}$ ) is quite common and the clinical features are well known. ${ }^{2}$ This case illustrates an unusual manifestation of Mandrax poisoning causing severe peripheral motor and sensory neuropathy; no similar complication has apparently been described.

\section{Case Report}

A 73-year-old man complained of numbness, pain, and weakness in the legs and feet. He had been treated for Mandrax overdose six months ago when depressed, having taken 28 tablets in the evening. A few hours later the police found him wandering in the street confused. After gastric lavage at the casualty department he was transferred to the medical department, and treated supportively, recovering consciousness seven days later. The first treated supportively, recovering consciousness seven days later. The first thing he felt on recovery was that "my legs have gone." Later he developed numbness below the knees, together with

The legs showed definite wasting of the anterior compartments as well The legs showed definite wasting of the anterior compartments as well
as of the calves. There was no dorsiflexion of toes or ankles and there was a as of the calves. There was no dorsiflexion of toes or ankles and there was a bilateral foot drop. Both knee jerks were depressed, the ankle reflexes were present, and there was no plantar response. Vibration sense was lost below the iliac crests and joint position sense was virtually absent in the toes and grossly defective at the ankles. Below both knees sensation to touch, pin prick, hot and cold was lost. The results of extensive laboratory and radiological investigations were normal. An electromyogram showed findings characteristic of a peripheral neuropathy.

\section{Comment}

These findings leave no doubt that this patient had peripheral neuropathy and the time relation to the overdose would implicate Mandrax as a causative agent. The antihistamine component of Mandrax does not appear to contribute appreciably to its toxicity ${ }^{3}$ and 